\title{
A "Headless" Native Talks Back: \\ Nidoish Naisseline and the Kanak \\ Awakening in I97os New Caledonia
}

\section{David Chappell}

\begin{abstract}
We, the headless bodies incapable of discerning good from bad, as many missionaries still pretend, and of making effective decisions concerning our own life, must be commanded, evangelized, Hellenized, transformed into Greco-Latin creatures, for fear that we would sink more deeply into our wickedness. A "no man's land" separates the Kanak body from white intelligence, and whoever decides to violate that "taboo" frontier exposes himself to criticisms from the defenders of the colonial system.
\end{abstract}

Nidoish NAISSEline, Cité Nouvelle, I970 (AJ-PC) ${ }^{1}$

\begin{abstract}
$\mathrm{T}_{\mathrm{h}}$ hese bitter words from a young Kanak activist in New Caledonia, spoken in his own defense at his sedition trial in August 1970, attacked what he perceived as the arrogance of the French colonial ideology of la mission civilisatrice (civilizing mission). ${ }^{2}$ In fact, Paris had often preached modernizing assimilation but had never spent enough money on the education of its overseas subjects to produce more than a small number of so-called évolués, leaving the colonized majority in a segregated, lower status that in practice the French called "association" (Hargreaves I967, I34-I43). ${ }^{3}$ For most indigenous people in New Caledonia, that meant segregation on native reserves run by appointed chiefs and gendarmes for a century. French marines, convicts, settlers, and mining companies took over 90 percent of the main island, Grande Terre (Big Land), and extracted forced labor and taxes from the dispossessed Kanak, who would supposedly, over time, "profit from the benefits of the French presence" (Merle I995, 304). Post-I945 political reforms granted the Kanak people citizenship
\end{abstract}

The Contemporary Pacific, Volume 22, Number I, 37-70

(C) 2010 by University of Hawai' $i$ Press 
and voting rights, but decolonization in the French Pacific hinged on the assumption that civic equality would negate separatism (Aldrich I993, $49-68){ }^{4}$

This article is not a history of the Kanak anticolonial movement per se but rather an intellectual mini-biography focusing on Nidoish Naisseline. ${ }^{5}$ Because he was a high chief's son, his journey from a Protestant mission school on an outer island, Maré, to the Sorbonne in Paris and home again highlights in particular ways the struggle that Western-educated leaders in the Pacific have often waged against outsider attempts to define their identity. Alban Bensa and Eric Wittersheim have collected and annotated texts by Jean-Marie Tjibaou, a former priest who gave his life for the Kanak cause (1996), ${ }^{6}$ and in this journal the two authors published a valuable article in which they suggested that Kanak nationalists drew inspiration from a variety of anticolonial influences and melded them syncretically with indigenous cultural perspectives (Bensa and Wittersheim 1998, 379-380). Tjibaou became well-known to English-speakers in the region because of his key leadership in the Kanak uprising of the I980s. ${ }^{7}$ Naisseline's political thought remains mostly buried in Frenchlanguage archival sources from the I960s and I970s, because his political star waned just as Tjibaou's rose. Yet in Paris in the 1960s, Naisseline and other students from New Caledonia encountered revolutionary ideas and participated in the student-worker revolt of May 1968, before Tjibaou arrived in France to study. Naisseline returned home in I969 to help found the radical Foulards Rouges (Red Scarves), a protest group that grew into a pro-independence political party by 1976, when Tjibaou was still a moderate autonomist. Naisseline's syncretism of Third World and Oceanian discourses sparked the "Kanak Awakening," the I970s intellectual and activist genealogical roots of the Kanak uprising. He is still a political leader today, yet his discourse has shifted in focus toward indigenous cultural rights and local autonomy. Like other indigenous Pacific leaders, Naisseline has had to adjust to challenges from changing internal dynamics and intruding globalization.

\section{Becoming a Francophone KanaK}

The indigenous people of New Caledonia speak about thirty languages, and their ancestors arrived on Grande Terre and neighboring islands over three thousand years ago. ${ }^{8}$ The Lapita dentate-style pottery usually associated with voyages by ancient Austronesian-speaking peoples through Mela- 
nesia into Polynesia was first discovered on Grande Terre in $1952 .{ }^{9}$ In the colonial context of the era, the archaeological find inspired pro-French loyalists to imagine that Lapita-makers were light-skinned like the Ainu of Japan, giving rise to the argument that, like themselves, Melanesians were later arrivals to the archipelago and therefore not truly aboriginal. This settler myth also posited that the dark-skinned Melanesians destroyed a more advanced Austronesian civilization, which had created intensive agriculture and decorative pottery, as demonstrated by taro terraces on Col de Pirogue and Lapita sites. French settlers were thus seen as restoring the high standard of living once enjoyed by their fellow light-skinned predecessors, not unlike Hebrews returning to the promised land (Brou I977; NC, 5 Oct I982). Yet recent work by archeologists such as Christophe Sand and Patrick Kirch shows that the taro terraces date only to the late first millennium AD, nearly two thousand years after the first Lapita site and long after Lapita pottery had given way to local plainware styles. Nor did the seafaring Austronesian speakers practice intensive agriculture (Kirch 2000; Sand 2005). Austronesian is more a linguistic than an ethnic category, so projecting current racial imaging onto ancient populations is problematic, as studies of Lapita-linked skeletons at Teouma, on Efate in nearby Vanuatu, demonstrate. ${ }^{10}$ Ironically, considering the title of this essay, the buried bones at Teouma are headless. ${ }^{11}$ In Oceania, the head is the locus of spiritual mana and was often buried apart from the rest of the body. Another form of "headlessness" arose during the Kanak rebellion of I 878, when the victorious French took the severed head of rebel Chief Ataï to France. The Paris Anthropological Society pronounced it a likely missing link to apes (Dauphiné 2007,73 ). In a sense it was that lost mana, that intellectual discursive voice and cultural authority, that Naisseline, heir to a high chief, wanted to restore to his people. The Foulards Rouges compared him favorably to Ataï.

Naisseline's home island of Maré lies between Grande Terre and Vanuatu, in the Loyalty Islands (or Islands Province) of New Caledonia. As in the rest of the region, its precolonial history is a complex story of clan migrations, exchange networks, wars, and cultural change that is difficult even to summarize let alone use to justify pinning quasi-racial images onto French-labeled tribes. Maré was a vortex of superficial categories: Austronesian, Melanesian, and Polynesian. Several chiefdoms emerged by the early nineteenth century, one of which was Guahma on the west coast, ruled by the Naisseline family. This polity arose after a war known in oral tradition as "the massacre of the Eletok" (or elder heads). Schol- 
ars have described it as an uprising by immigrant clans against the older lineages of "land masters" who refused to allow intermarriage lest they risk losing their authority to newcomers. Sometimes the Eletok clans are characterized as Melanesian while the rebel migrants are portrayed as Polynesian, perhaps Tongan (via outliers like Wallis/Uvea). However, considering the clan intermingling that had occurred over the centuries, such shorthand ethnic images are problematic. In fact, Melanesians of New Caledonia often allowed useful immigrants to serve as war leaders or diplomats toward other outsiders, while keeping control over the land in the hands of the first settlers. But on Maré, the Eletok lost authority over the land as well as other leadership roles (Dubois I98I). Because the Naisselines of Guahma began their rise to prominence as war leaders during the overthrow of the Eletok, anthropologist Jean Guiart wrote, "Maré was thus already, before the letter, a colonial society" (I963, 349). This rather loaded pronouncement was later used against Naisseline at one of his trials, when the French prosecutor tried to counter the young man's anticolonial rhetoric by claiming that the defendant's own clan had once conquered Maré, whereas French colonization there was relatively bloodless. Naisseline dismissed such reasoning as anachronistic (Voix $d u$ Cagou, 25 April I972 [ATNC]). ${ }^{12}$

The politics of the Naisselines had always fluctuated in changing contexts. The ancestors of the young sociology student on trial in 1970 had traded sandalwood and provisions to foreign ships for firearms, allied with Samoan and English Protestant missionaries in crusading wars in the name of Jehovah, and sent young men off to work as seamen on foreign vessels or to labor on plantations in Queensland, Australia, in order to bring back sailors' chests of exotic trade goods, including firearms. By I 862, the London Missionary Society proclaimed one Nidoish Naisseline as king of Maré, so his old enemies sided with Marist Catholic missionaries. After French administrators arrived in I864, that Nidoish fought against his now-Catholic enemies under the tricolored flag, but was arrested because the new colonial governor was anticlerical. In I 898, the Guahma chiefdom welcomed the French Protestant Société des Missions Evangéliques de Paris (which replaced the British London Missionary Society on Maré), and two years later, at the urging of the Protestant missionaries, the French administration declared Maré a native reserve whose land could not be alienated to white colonists. That stroke of good fortune contrasted starkly with colonization on Grande Terre, an island with valuable minerals and a French penal colony. The sons of Naisse- 
line chiefs attended secondary school in Noumea, the colonial capital on Grande Terre, and the Guahma chiefdom survived by adapting to change, as new layers of identity intertwined with indigenous customs (Howe I978; Dubois I98I).

In I940, Henri Nidoish Naisseline II rallied to Charles De Gaulle's Free France and sent subjects to fight abroad. By I945, however, he joined the Communist Party because war veterans complained about their lack of rights. In 1946, De Gaulle made good on his promise to extend citizenship and voting rights as a reward for wartime support, so Henri II soon returned to the Gaullist fold, was elected to the Territorial Assembly in 1957, and received the Legion of Honor for his loyalty to France in 1959 (Dubois I98 I, 43-45). Born in I945, Henri Nidoish Naisseline III, the future radical, attended a Protestant primary school on Maré until I955, then the Lycée La Pérouse in Noumea, and went on to France in I96I, where he earned his baccalaureate at the Lycée Jean-Jacques Rousseau near Paris. His older sister had suffered prejudice over their father's brief time in the Communist Party and had fallen ill, so the elder Naisseline wanted his son to finish school in France and study law. Instead, young Nidoish earned an advanced degree in sociology at the Sorbonne, specializing in the identity crisis among young Kanak who moved to urban centers like Noumea to study or work. The Protestant pastors encouraged students to learn about modernity through the lens of Christianity, but there was also a sense that the students were chez eux (at home) in their traditional setting on Maré, a native reserve. Naisseline's education was thus shaped by custom, Protestantism, ${ }^{13}$ and his father's shifts from Gaullism to Communism and back again. He was expected to use his education to help his lineage on Maré as a chief. Maurice Leenhardt was a missionary-anthropologist who had spent his career educating and writing about the Kanak (see Clifford 1992; Leenhardt I979 [1947]). In 1962, his son Raymond told other young Melanesian students in France to strive to acquire "critical thinking that Nidoish found surprising when arriving at the Lycée: to reflect on their own about the problems that they encounter here and that present themselves regarding Caledonia; and in this moment when Caledonia is experiencing a crisis of growth, [when] the two [ethnic] communities are in the process of trying to understand each other, it is important that the young people who are training here develop a sense of responsibility" (Correspondence of Raymond Leenhardt, letter from Leenhardt to Waheo, I9 Aug I962 [ATNC]).

Naisseline arrived in France just when the Algerian war of indepen- 
dence was ending. He met Africans who introduced him to the writings of Frantz Fanon; but unlike Fanon, who had described the racism he encountered after coming to France from Martinique (Fanon 1967 [1952]), Naisseline found his Protestant milieu quite welcoming. He told me in a $200 \mathrm{I}$ interview that, ironically, he had rediscovered his indigenous identity in France, and it was not France but rather French colonialism in his homeland that he opposed (Naisseline 200I).

\section{INDIGENOUS IDENTITY AND DECOLONIZATION}

In I960s Paris, Naisseline encountered the revolutionary side of French tradition, as well as the global youth movement against imperialism and conformity. He dialogued with and protested alongside Marxists, but he says he concluded that they were as prone to lecture natives as the colonial assimilationists were. Meanwhile, back home in New Caledonia, France was unilaterally withdrawing the autonomy that it had already given the territory in the I950s. A rough analogy would be if the United States Congress reverted Hawai'i's status from a US state back to a territory despite protests from its duly elected representatives. ${ }^{14}$ The reason for the regression was the strategic importance of nickel, which is one of New Caledonia's most significant resources. Among other things, nickel is used as a hardening alloy in tank armor and missiles. De Gaulle was developing French nuclear weapons by testing bombs, first in Algeria until it became independent, then in the Tuamotu Atolls near Tahiti. The Société le Nickel had a monopoly over New Caledonian mining, and its owners, the French Rothschilds, had close ties to Premier Georges Pompidou, a former employee. Massive immigration during the nickel boom would make the Kanak a demographic minority and undermine the autonomist Union Calédonienne (UC) (Le Borgne 2006; Firth I987; Bouvier 1967).

Naisseline joined the New Caledonian student association in France, which in 1962 began to publish a bulletin called Trait d'Union. The association was officially nonpolitical, but contributors to the bulletin were concerned about the increasing loss of autonomy, overdependence on nickel mining, and new immigration that threatened to marginalize not only the Kanak but also many white Caledonians in their place of birth. Progressives like Jean-Paul Caillard and Max Chivot transformed the publication into a debate forum and, along with Naisseline, attracted a lively cohort of activists. In 1965, for example, Chivot reviewed the academic thesis of Apollinaire Anova-Ataba and interviewed the author, who was 
only the third Kanak to be ordained as a Catholic priest. Anova-Ataba saw in the Union Calédonienne real hope for building a multiethnic "Caledonian personality," and he revered Chief Atai for leading the anticolonial revolt of ${ }_{1} 878$ in the name of liberty. That same year in Trait d'Union (Feb-March I965 [AJ-PC]), Naisseline published two Mareen traditional songs with his own explanations. He had learned them on a visit home on summer vacation, when as a chief's son, he was expected to dance with the other young people: "I had to learn the movements for two hours.... Nearby were the elders: I had to go see them, so they could tell me some legends" (Correspondence of Raymond Leenhardt, letter from Naisseline to Weben, Aug I963 [ATNC]).

In 1966, Trait d'Union began to publish a series of essays by Naisseline that showed his working familiarity with anticolonial writers like Fanon and Albert Memmi as well as European philosophers from Aristotle to Jean-Paul Sartre. The first essay, titled "Canaque Customs and Western Civilization: Face to Face?" opened with the question, "What must the European do to help the Kanak?" In Noumea, he said, people had replied, "The white must collaborate with the black to 'civilize' him, implying that it was only the indigenous person who needed to change, to fit an absolute Western model." In contrast, he wrote that when he asked young people in France the same question, they proposed collaboration of a different sort: "It's first to discover, to understand, to respect each other. Collaboration requires equals.... It defines intimate and frequent relations between two individuals, two groups, two nations" (Trait d'Union Jan-Feb I966 [ATNC]). This argument was similar to Fanon's universalist goal "to recognize and accept the reciprocal relativism of different cultures, once the colonial status is irreversibly excluded" (Fanon I969 [1964], 44). Yet Naisseline was grounding his ideas in personal experience, and throughout his career he would repeat the theme of seeking mutual respect and equal recognition for Kanak identity. In the same I966 essay, he went on to criticize some missionaries for trying to sever the bond between Kanak and ancestor worship, which defined them in terms of their clans. The colonial system "breaks a civilization without replacing it," he argued, as young Kanak who moved to Noumea found out: uprooted and marginalized, they lived in cultural limbo. Yet the second kind of collaboration, Naisseline argued, was more in line with what Maurice Leenhardt had once written: whoever "seeks to discover [the native's] true personality is led to respect and admire it." In Noumea, the chief's son was taught to raise himself up to the level of the European, but curious Parisians 
wanted to learn about his culture. Naisseline suggested that Kanak should try to rectify the imbalance, the spiritual emptiness caused by assimilation policy: "We Canaques have evolved toward the European . . . in their turn, Noumeans must break away from certain prejudices" (Trait d'Union, Jan-Feb I966 [ATNC]).

The next year, Naisseline wrote an essay for Trait d'Union entitled "The Black and Language," in which he criticized the inferiority complex that young Kanak often acquired in French schools. "To speak assumes a culture, it carries the weight of a civilization," he wrote. "In the tribes of New Caledonia, natives who speak French fluently are demi-gods, regarded as quasi-whites." Kanak interpreters who helped the police or missionaries to translate gained a certain authority, while conversely, Kanak who could not speak French were looked down on. For the young Kanak, going to France was thus like entering the world and affirming the humanity that he supposedly lacked: "it's from there that Montesquieu and Rousseau come to him." In fact, whoever goes home again after a long time in France, the chief's son wrote, answers people only in French "and often no longer understands the local dialect" - until suddenly "his father gives him a kick and the amnesia disappears, a peculiar therapy!" Naisseline disagreed with Sartre, ${ }^{15}$ who said that black nationalist poets would turn against the French language, because in New Caledonia the indigenous languages were banned from schools and all publications. Moreover, there were thirty local languages, and "Canaque" identity arose from colonial discrimination, so French served as a vehicle for subversive mobilization: "When an intellectual succeeds in proving he is as intelligent as a white, we reply to him that intelligence never saved anyone." White settlers spoke French to natives as if to children, using the familiar "tu" form of "you," while reserving the more formal "vous" for themselves. To Kanak, the colonizer spoke a pidgin known as petit nègre (little nigger), as if saying to people of color, "Stay where you are." Naisseline urged Kanak to refuse to let others define them, and to become a new type of person, not one who reminds people of somebody else (Trait d'Union, Dec I967 [AJ-PC]).

By early 1968, Naisseline was quoting Georg Hegel on the master-servant relationship, in which the master imposes his will on the "other" and thus affirms his own self-identity: "It's on the recognition by that other that his value and his human reality depends." Sartre, of course, also built on this concept, arguing that because the possessive gaze of the "other" could reduce a person to a mere object instead of a conscious subject, individuals had to turn the tables and take back that gaze, and by extension, colonized 
people should seize freedom from their oppressors in order to redefine themselves (Sartre I992 [1943]). Hegel conceded that the servant had a dependent consciousness; hence there was a dialectical tension between master and servant that rested on mutual but unequal recognition (I953, 399-406). In his I968 essay, Naisseline argued that French colonizers in New Caledonia had recognized Kanak only as inferior beings who needed raising up to the European ideal, but that the Kanak rejected servant status and sought recognition of their human reality and of the value of their own civilization. Naisseline said that when De Gaulle had granted citizenship and voting rights to Kanak after World War II, it was the result of paternalistic Christian charity, not the reward of struggle; indeed, since the Kanak retained his servant status and did not become equal to the master, the new rights did not feel as if they really belonged to the Kanak. "The Kanak is a slave," Naisseline wrote, "who has been authorized to eat at the master's table." He contrasted the reforms in New Caledonia with the civil rights struggle of African-Americans, who had shed their blood to change laws. Kanak, he argued, wanted to preserve their alterity rather than lose their identity through French gifting. Again transcribing Fanon (I968 [196I], 316), Naisseline said, "the Kanak wants to participate like the White in the construction, in the birth of a fully human world, that is, of recognition" (Groupe d'Action pour l'Indépendance Accéléré de la Calédonie, Jan-March I968 [AJ-PC]).

Meanwhile, influenced by the writings of Régis Debray, Guy Debord, and other leftists, a multiethnic cohort of radical New Caledonian students, led by Naisseline and Caillard, had formed a political study group. De Gaulle's regime was determined to strip their homeland of still more self-governing powers, despite the continuing electoral majority held by the Union Calédonienne in the local assembly (68 percent in 1967). A key issue was the UC proposal to allow a Canadian nickel mining company, INCO, to break the Société le Nickel monopoly, an idea that the French president and Premier Pompidou refused to allow to happen (Le Borgne 2006, 395, 527). During the May I968 student revolt in France against the elitist university system, which gained support from the radical labor unions, New Caledonians organized an Action Committee for Caledonian Autonomy and the Defense of France. It voiced support for the "true" France, that of the people, and of liberty, equality, and fraternity (Action Committee 5/68 [AJ-PC]). The conservative home press viewed Naisseline as a wild Marxist who promoted revolution alongside Daniel Cohn-Bendit, a student leader of the enragés (enraged) who shut down the Sorbonne 
in the name of freedom and reform. But in his interview with me, Naisseline said that he and "Danny the Red" had only crossed paths a few times, and that he saw the anticolonial struggle as different from the class revolution advocated in France. In June 1968, Pompidou led the Gaullists to an impressive election victory on a law-and-order platform, with collaboration from the old-guard labor unions and leftist parties. The Billotte laws soon took away New Caledonian control over mining, investments, and even municipal elections (Charlot I97I; Le Borgne 2006).

In the December I968 issue of Trait d'Union, Naisseline published an essay titled "The Indigenous Student in France." The essay opened with a Kanak oral tradition about an old sorceress who disguised herself as a young beauty to seduce a handsome man who had a large harem that made too much noise. She manipulated him into destroying his harem and returning with her to her home on the beach; only too late did he realize the terrible mistake he had made. Naisseline said that the story was analogous to French education and the missions' misleading young Kanak into cutting themselves off from their families and customs, by claiming that precolonial life was barbaric. Adapting ideas from Fanon and Memmi, he suggested that, culturally speaking, an uprooted Kanak student went through three successive stages: first, attempted assimilation driven by shame at having savages for ancestors; second, disillusionment when he realizes the colonial trick being played on him, a realization that results in a total rejection of the West and a futile quest to return to a mythic indigenous civilization; and finally, after a double sense of alienation sinks in, "the native decides to live with his time" instead of in "an imaginary future or an idealized past."

From then on, it will no longer be a question for him to resolve his problems in the most European or the most Melanesian way possible, but in the most just manner. For that, the events of May furnish us with a beautiful example. The indigenous students of Paris participated on the barricades not to follow the French students, not to obey custom, but for this exact reason ... before this insolent and inhuman regime, no hesitation is possible. The indigenous student now understands that he is tied to his present, that he belongs inescapably to his epoch and that all present problems concern him. (Trait d'Union, Dec I968 $[\mathrm{AJ}-\mathrm{PC}])^{16}$

In early 1969, the radical study group formed a new student association and came out with a new bulletin, Canaque Homme Libre (Kanak Free Man). Naisseline contributed an essay titled "The Black Aspect of 
the White Problem," in which he responded to criticism from the settler press back home that a handful of leftists and the Union Calédonienne had duped Kanak students in France into unpatriotic behavior. Noting how common it was for colonial elites to refuse to accept that their longtime native subjects could possibly think up a revolt on their own, despite obvious evidence to the contrary, he argued that the Europeans in New Caledonia remained "obstinately attached to a Darwinian conception of interracial relations specific to the 'civilized' of the nineteenth century. They attribute to natives qualities like great football players, charming folk dancers, incomparable battle criers, but do not recognize their ability to think, to love, to choose between good and evil." In other words, to concede that indigenous people could think would require acknowledging that they were on the brink of leaving the animal kingdom and becoming human. Naisseline reminded his readers that in I93 I, by which time the Kanak were already practicing Christians, some were brought to France to be displayed in the Paris Colonial Exposition. They were told to take off their clothes, stop speaking French, and pretend to eat raw meat; a few were even traded temporarily to a zoo in exchange for some decorative live crocodiles! ${ }^{17}$ (Canaque Homme Libre, Feb I969 [AJ-PC]; see also Mwà Véé I3, July I996)

Adapting Debord's concept of a media-manipulated "society of the spectacle" (1983 [1967]), Naisseline called the settler press and church back home "organs of intoxication" that enabled colonialism to "drug" the population into accepting what the economic elite claimed, namely, that the country was a tourist paradise, when in reality mining was enriching a few, proletarianizing many, and ruining the environment. He accused the colonial administration of violence toward the oppressed and, in true soixante-huitard ('68er) spirit, said there were only two choices left for those who hoped to restore the "Melanesian personality": dialogue or revolt. "Dialogue between the two ethnic groups requires a reciprocal recognition," he wrote, but, given the racial power inequity in New Caledonia, "we are currently in the right not to believe in the possibility of a true dialogue." He concluded, "A new combat is born, that of liberating the indigenous person: to give him a chance, to see him finally restored in his dignity and responsible with all Caledonians for the happiness of all" (Canaque Homme Libre, Feb I969 [AJ-PC]). We can see in the student writings of Nidoish Naisseline a steady progression. He had begun by contrasting the attitudes of local settlers with those of metropolitan French toward Kanak identity and stressing the need for mutual recognition. $\mathrm{He}$ 
later proposed his own version of the three stages of development in the self-perception of the colonized, and then called for activism against racism and colonialism, to improve the lives not only of Kanak but also of other New Caledonians, including the poor descendants of convicts and of Asian indentured laborers. His approach mixed Kanak cultural nationalism with leftist universalism, in a classic example of Third World syncretism similar to the works of Fanon, Memmi, and Amilcar Cabral. ${ }^{18}$

\section{The Foulards Rouges and Palika}

In July 1969, on the day before Bastille Day (when, ironically, French residents and military units in Noumea celebrated the French Revolution), people on their way to Sunday morning church noticed that the walls of public buildings had new decorations: spray-painted graffiti that proclaimed slogans such as "Down with Colonialism," "Long Live Free Caledonia," and "Independence Yes!" Three white Caledonians, including Caillard, were arrested for "the degradation of public monuments" and then released, pending trial. But three weeks later, just before their trial, more graffiti slogans appeared, such as "Whites Out, Caledonia for the Canaques," and "The whites came with the Bible to civilize us. We had the lands. Now they have the lands, and we still have the Bible." The new graffiti also urged a boycott of the Pacific Games in Port Moresby, Papua New Guinea, as concealing the oppression of the Kanak people: "Canaque athletes, follow the example of our American brothers! Down with Racism! Long live human equality!" (Voix du Cagou, I6 July, 7 Aug I969 [ATNC]). This time Naisseline was arrested, but athletes from Maré who traveled to the Pacific Games raised their fists in protest, as several African-Americans had done the year before at the Olympics in Mexico City. They also wore red bandannas around their heads, the foulards rouges, which became the name of a small, multiethnic coalition that melded anticolonial leftism and Oceanian cultural nationalism (Naisseline 200I).

In early September, Naisseline and others were arrested again, this time for carrying copies of an anticolonial tract that the French police claimed was a "call for murder." There had been rumors that the annual 24 September commemoration of the French taking possession of New Caledonia in 1853 would be disrupted by protests, but the second arrest of Naisseline backfired. About three hundred supporters-mostly people from Maré rallying around their chief's son-crowded outside the police station, pounding on the door and throwing stones and bottles. The police 
charged, and a riot ensued that spread across Noumea. If Naisseline had not inspired such protests, the Foulards Rouges might have remained a handful of leftist students home on holiday, although they had some support from local labor unionists. But as heir to a high chief, Naisseline brought with him a whole tribe of followers. Thus, his arrest, the riot, and his subsequent trial sparked what became known as the Kanak Awakening, or Réveil Canaque-a phrase that subsequently became the name of a radical bulletin published by the Foulards Rouges. The historical situation was a powder keg waiting to be ignited, as France had unilaterally withdrawn self-governing powers from the territory, a nickel boom had attracted thousands of loyalist immigrants-some of whom organized committees of "self-defense" after May I968 (many were former Algerian settlers) - and labor unions were demanding higher wages due to rising nickel prices and a devaluation of the French franc that had further inflated the already high cost of living. The French high commissioner wrote to Paris, "In such a climate, the action of small groups of extremists can be an effective catalyst in a moment when the habitual political structures find themselves weakened." 19

The graffiti painters were released with suspended sentences and fines, thanks to help from human-rights lawyers, but the rioters and the authors of the so-called call to murder tract received more attention. Written in French, the tract described a case of racial discrimination in a local restaurant, and quoted Sartre as saying that when the slave says "no," he begins to exist; it closed with the English expression "Freedom Now." The tract was translated, illegally, into two indigenous languages, that of Maré (Nengone) and of Lifou (Drehu), but the French prosecutor could not prove that Naisseline had written it. In fact, the most violent language was said to be in the Drehu version, which was written by a Kanak law student who had actually experienced the discrimination (the student would later became the first Kanak judge) (Trolue 200I). The court trials became opportunities for the protesters to publicize their arguments in the media, and while they were in jail they bonded more than ever before and made useful contacts with established politicians like Yann Céléné Uregei, a Kanak who would soon break from the Union Calédonienne and form his own political party (France Australe, 2 Nov I970 [ATNC]). From prison, Naisseline wrote in an unpublished letter:

We have decided to say no in order to become ourselves. "The Canaques, we know them," say the colonizers. "They always say yes and we can make them 
accept anything." However, deep within ourselves, we would like to say "no." ... Our elders, their memory full of blood, told us stories of imprisonments, of lynchings, of beatings, of which they were victims, for having dared to think and to say what they thought. . . Nothing is more intolerable than seeing a native hesitate (or scratch his head) to knock on the door of a European to demand from him what he is due.... We are struggling for humanity and not against the White. ... The condition for racial harmony in New Caledonia [is that] each ethnic group should develop its personality. (6 Sept I969 [AJ-PC])

Naisseline received a one-month prison sentence for supposedly calling for murder and was released for time already served, but he appealed, and his speech at his I970 retrial, which provides the opening quotation in this paper, was published in the first issue of Réveil Canaque (RC) and in a leftist bulletin in France. He criticized the local press for dehumanizing the Kanak by portraying them as unthinking beasts, which in the process dehumanized the colonizer by denying his own capacity for compassion. Such thinking could also be found in Sartre, who said in a preface to Memmi's The Colonizer and the Colonized that the colonizer's self-dehumanization resulted from his need to "assume the opaque rigidity and imperviousness of stone" (I967 [I957], xxviii). But it was also traceable in Western philosophy back to Plato, who had said that a master who mistreated his servant revealed his own flawed character by failing to uphold right and reject wrong. Naisseline's complaint about French attempts to Hellenize him into a Greco-Latin creature implied that the assimilation policy had failed to displace, and indeed reinforced through colonial inequality, the more common practice of association. The policy of segregation enacted in French colonial law the ancient Greek (and Hegelian) mind/body dichotomy, which defined a slave or servant as intellectually headless and thus mentally dependent. Plato equated reason with the ideal master and the body with the servant, who could take orders but not originate ideas (Laws IV, 720; VI, 777). In his famous cave allegory, in which chained captives mistook for reality the shadows cast on the wall by a fire, Plato admitted they had souls that could learn once outside in the light of day and even teach others (Republic VII). But Aristotle defined the natural slave as no more than a living tool to be owned and used at will, whose function was to use his body like a tamed animal, and who had only the intelligence to understand commands (Politics I, v, I254b, I6; Pagden I982, 42-45). The educated Kanak was in effect trapped between the head and the body, as if in a noose camouflaged by the white hunter, choking, angry, rebellious, and ready to talk back eloquently to his captor. 
Naisseline paraphrased what Western philosophy had preached: "We have only the body as our domain, which means that we do not possess intelligence, that quality being specifically reserved for the colonizers." Then he countered that when Kanak dared to show their ability to think and write, it caused a fear of disorder and panicked their racist rulers, who arrested them and accused them of plotting murder. He admitted that he was indeed guilty of wanting to commit two murders, that of the myth of white superiority and that of the myth of Kanak savagery. He echoed Memmi, and recalled Kanak elders who had passed down the oral memory of the beheaded rebel Chief Ataï, saying, "The colonial system attains its goal to the degree that it animalizes the colonized and the latter accepts his inferiority and hates himself." Even integration demanded that the Kanak let go of their identity. But he declared, "To the refusal of self that colonialism imposes on us, we oppose the acceptance of self." In considering the struggle of poor European ex-convicts and Asian and Polynesian contract laborers in industrial New Caledonia, he added, "Whites must understand that the Canaque problem is a Caledonian problem, that our problems are theirs" (RC, Sept 1970 [number I]; Cité Nouvelle, Nov 1970 [both AJ-PC]).

In a 1970 article published in Christianisme Social, a metropolitan Protestant journal that espoused church activism on behalf of the working class, Naisseline said that, unlike Western notions of the autonomous individual, his culture situated personal identity in a web of social relationships: "Canaque education seeks to produce a personality careful toward others, extremely hospitable, strongly dependent and little inclined toward individual affirmation." He cited Robert Jaulin, ${ }^{20}$ a French anthropologist who condemned the "ethnocide" waged against indigenous African and Amerindian cultures by a predatory, industrial West, which he said had already atomized its own peasantry and then, instead of spreading civilization overseas, actually caused "decivilization." The bourgeois revolution of 1789 had empowered individualism to the extent that it built mistrust of the Other into competitive human relations and objectified nature for easier exploitation. "Relations between the colonizer and the non-white who has accepted to deny himself, are like hypnotism," Naisseline wrote. "In hopes that we will see ourselves possess one day the secrets of our hypnotizers, our parents encourage us to work hard in school." Citing Fanon, Naisseline noted that the affective characteristics of Kanak civilization were displaced by a conditioned desire to copy colonial oneupmanship and to prove oneself less savage than others, but to no avail. 
The promises of assimilation were not fulfilled for young Kanak, because their educational and economic opportunities were so limited. The riot in Noumea in 1969 was thus a spontaneous demand for dignity, he argued, an expression of unity and the beginning of a search for "an authentic Canaque personality" comparable to the struggles of other oppressed peoples in Africa, Asia, and America. He said that he drew inspiration from Aimé Césaire's négritude poetry ${ }^{21}$ and the Black Panthers' demands, and he closed with a Léopold Senghor-like image of the serenity of rural village life, where "a rose is not this thing that we acquire in a market in exchange for some pieces of money, but a flower that we put in the hair of a Kanak beauty" (Christianisme Social, I I Dec I970 [AJ-PC]).

The Foulards Rouges recruited new followers in schools, held meetings in cultural association halls, and distributed their bulletins in both Noumea and the interior. Educated Kanak women such as Déwé Gorodé and Susanna Ounei also joined the movement. Gorodé recalled accompanying her cousin to a meeting organized by the Foulards Rouges and hearing that Naisseline and some of her former classmates had been arrested: "It was a shock for me and marked the beginning of my awareness about the independence struggle" (Gorodé 200I, Io). Ounei remembered that as a schoolgirl she had resented the racial arrogance of her teachers and hoped someday for a way to combat such behavior: "My dreams became a reality in September 1969, when Nidoish Naisseline, the high chief['s son] of Maré returned to New Caledonia from France and established a political group called the 'Red Scarves"' (Ounei 1984). The loyalist settler press challenged Kanak indigeneity with the old white Lapita myth and mocked the white leftists as spoiled brats, but Kanak nationalists and white Caledonian leftists in the Foulards Rouges continued to work together while forming separate organizations. Labor unionists and Pacifists also collaborated with the young radicals, as did a few politicians who wanted autonomy restored, such as Uregei. ${ }^{22}$

In an early 1972 interview that was published in Cité Nouvelle, a leftist metropolitan review, and in AWA, a radical bulletin in Noumea, Naisseline explained the genesis and content of the Kanak Awakening. He said he had been studying in France for ten years, during which time he had obtained three degrees and was now working on a master's thesis in sociology, about the search for identity among young Kanak from the Loyalty Islands (like Maré) who migrated to Noumea. When asked why he was doing such research, Naisseline replied that the Kanak youth on whom his work focused were doubly marginalized, from their home society and 
from settler-dominated Noumea. Thus emerged the new slogan "Canaque personality" (as opposed to the old UC phrase "Caledonian personality") among the first generation of young Kanak after the abolition of the segregationist indigénat policy in $1946 .{ }^{23}$ Although their parents had raised them according to traditional values on the reserves, they themselves had the freedom to move into town to work and study. The first of that generation whose consciousness had been raised about the identity crisis were those most westernized by French schooling at both the high school and university levels. Like fish out of water, they found that custom no longer determined their jobs or choices of spouses and that the dominant society in town regarded communal custom as inferior to individualism. The Kanak personality arose in rejection of the French view that they had no ancestral identity worth preserving, yet it did not reject modernity, Naisseline said: "what we want ultimately is for both the Canaque elders and the Europeans to recognize our right to choose for ourselves whatever is best for us in the two societies, because no one can do that in our place." The colonial system had disempowered customary chiefs and also discriminated against Kanak in jobs, he said, so that in the quest for a "modern" Kanak identity, "the domination at the level of the tribe and the exploitation at the level of the factory represent two sides of the same reality." Multiracial autonomy was the only path to justice, he argued, because the colonial courts condemned radical tracts and graffiti but hypocritically permitted right-wing loyalist tracts calling for violent "self-defense." Anticolonialists therefore needed greater unity and better organization to create a Caledonian consciousness of racial harmony (AWA 7, I972; Cité Nouvelle, April 1972 [both AJ-PC]).

On Maré in March 1972, Naisseline was again arrested, this time for asserting his role as heir apparent to the Guahma chiefdom. Accompanied by local Foulards Rouges, he intervened in a dispute between a Kanak shopkeeper and an aggressive French official by declaring, "You have no right to play gendarme. Don't come to make the laws here, we are in our home, get out! I don't care about your uniform. . . . This is not France!" This fierce claim to autonomy would become his cause for years to come. The Foulards Rouges portrayed Naisseline as a second Chief Ataï defending Kanak custom against colonialism, and represented him on the covers of radical bulletins as a Kanak Christ being crucified. Hundreds of sympathizers attended his trial and subsequent appeal, but he was sentenced to six months in prison for "insults and threats" toward an official. Réveil Canaque published two messages from Naisseline while he 
was behind bars. In the first, he said he was happy and in harmony with himself: "Other people more prestigious than me (King, Gandhi, Cleaver) have fought for their respective brothers; they knew prison and some even death." ${ }^{24}$ In the face of exploiters, one had the choice either to keep quiet or to revolt, "meaning that whatever the danger that threatens us, we refuse to abdicate our liberty, humanity and dignity." "What differentiates man from animal is in part choice," he wrote, "and in part . . speech. I chose to speak and to write about the condition of Canaques, I chose this path according to my conscience, freely." He admitted he had insulted an official but had no regrets, because he was defending the honor of Kanak against nineteenth-century-style behavior, which treated them as subhuman: "I don't respect the uniform of a man who agrees to wear it and commits a crime against humanity." The twentieth century had brought a progressive change of awareness that the slogans of the French revolution also applied to nonwhites: "Liberty, now it's freedom to be what one is, on condition not to harm another; Equality assumes equality among all men, equality among civilizations and cultures; Brotherhood: fraternizing is to recognize each other, because recognition, respect for cultural and human differences, is the foundation of Brotherhood. Those are the three concepts in their modern version" (RC, 2I April $72[\mathrm{AJ}-\mathrm{PC}])$.

In his second message, Naisseline responded to an accusation in the local press that he was simply an autonomist using indigenous custom for political ends. He pointed out that the French state appointed or removed indigenous chiefs according to their loyalty, beginning in the nineteenth century and continuing to the present day, as when the official he had stood up to had recently removed a chief from another tribe and replaced him with a loyalist. For over a century, the colonial regime had thus tried to make chiefs their valets, he argued, disrupting indigenous society: "To defend custom is to try to help the chief become once again the elder brother of the Canaques." Autonomy would advance that cause because it accepted equality between civilizations, but the Billotte laws of I969 that took away the self-governing powers of New Caledonia had reinstalled French sub-prefects in the Loyalty Islands, which were supposed to be indigenous reserves. ${ }^{25}$ Naisseline compared the Kanak struggle to that in Tahiti, where indigenous activists opposed French nuclear testing, and to the movement in Larzac in southern France, where local peasants opposed the installation of a military base-an intrusion that the satirical newspaper Le Canard Enchainé had described as an invasion of France 
by France! "It is not France who is colonizing Caledonia and Tahiti," Naisseline clarified, "but a bunch of conniving politicians in the service of big money, who, from Paris in the name of an unreal, fantasy France exercises control over the lands of France, the real France, that of the people, Caledonia and Tahiti being only pieces of an exploited France. ... The grievances of the Canaques are the same as those of the Bretons, Occitans, Corsicans, etc. They are those of a people who struggle for the right to be heard and respected" (RC, I9 May I972 [AJ-PC]).

Also in 1972, the autonomist Union Calédonienne lost the Territorial Assembly election for the first time in twenty years, due to rising loyalist immigration encouraged by the French state during the nickel boom (Henningham I992, 6I-63). The mayor of Noumea told l'Express (28 Aug-3 Sept 1972), "We must make whites, make metropolitans come here. That way, there will be no Canaque problem." But such tactics only radicalized the Kanak and Caledonian autonomists more, because they felt as though their backs were up against a wall of social recolonization. Even local-born whites sometimes resented the arrival of thousands of metropolitan migrants who often had better qualifications for jobs than they did (Bobin I99I). By 1973, the term Canaque was transformed into Kanak to indigenize and revalidate it, and the multiethnic Union Jeunesses Calédoniennes (Caledonian Youth Union, UJC) had begun to talk about independence for the Caledonian "nation" (RC, Sept I972; UJC 2 Aug I973 [both AJ-PC]). In the same year, the Foulards Rouges and the Union Jeunesses Calédoniennes declared 24 September (the date the loyalists normally celebrated the 1853 French taking of possession of New Caledonia) a day of "national" mourning. The following year, they contested the military parade on that day, after a prelude of confrontations between young Foulards Rouges and police on Bastille Day. Gorodé and other Kanak activists like Elie Poigoune had already formed a new faction called Groupe I 878, which organized young Kanak of Grande Terre around the issue of returning colonially alienated Kanak lands, and demanded Kanak independence from France. They took the lead in protesting on 24 September 1974, and at their trial, hundreds of sympathizers protested with a sit-in. The expression of solidarity led to more arrests, while others began hunger strikes. The radical anticolonial movement had been relatively small, but in 1975 , a Territorial Assembly delegation to Paris was told by Premier Jacques Chirac that autonomy was no longer possible, and that only two choices remained: departmentalization or independence. ${ }^{26}$ Led at first by Uregei, 
autonomist political parties in the Territorial Assembly with mostly Kanak members began to shift toward a demand for independence from France (Dornoy I984).

Caillard founded a new leftist paper, Les Calédoniens, and interviewed various leaders, including Naisseline, about the independence issue. By I973, Naisseline had gotten married and had also inherited his father's chieftaincy in Guahma. Had these transitions in his life changed his politics? He replied that his customary responsibilities took up more time now than his political militancy, and he had temporarily dropped out of activist groups. But he still did not welcome French officials in Guahma, and he kept in contact with radicals as well as young migrants in Noumea. Asked if the Foulards Rouges would continue as a movement, he said yes, more than ever, but now the risk was that the young Kanak attracted to the Foulards Rouges would come to see it as an exclusive cult and close themselves off to both custom and cash employment. The goal of the Foulards Rouges, Naisseline said, was to engage with the population, both old and young, and to undertake analytical reflections aimed at precise actions, for which they must be trained. Did Naisseline see Groupe 1878 as a rival to the Foulards Rouges? He responded no; the Foulards Rouges had mostly been Loyalty Islanders and had divided into three subgroups, one for each of the main outer islands, while Groupe I 878 mobilized the Kanak tribes of Grande Terre. It surprised him how fast the idea of independence was spreading among the Kanak population, with support even from some elected leaders.

When asked for his definition of independence, Naisseline answered, "there are as many independences as there are independent countries, [and] because of that there is not a model that we can import here." Like other Kanak activists, he said the slogan, "Kanak Independence," needed more content, and to achieve that, Kanak needed to remember to dialogue with others: "For the Administration, it means the loss of Caledonia. For us, Independence means to win something. We thus have everything to gain and nothing to lose, our objectives are opposed . . . the Administration behaved as if the Melanesian didn't exist, but today the Kanak wants to exist." He went on to argue, "All the claims for redress whether in Africa or elsewhere have always begun with cultural grievances and in particular to struggle for the recognition of values. . . . For me it's the primary combat." Without cultural recognition, Naisseline warned, independence would fail. He also said that independence was not only to help the Kanak exclusively, as some loyalists openly feared: "we share 
common situations with Europeans, Wallisians, Tahitians ... and we are under the domination of a common enemy. . . . All the exploited people are for me legitimate allies that we must not ignore." The independence movement needed to reject racism and disunity, the classic weapons of those who oppose self-government. Naisseline said it was appropriate for the Kanak, as first occupants of the land, to be first to speak of independence, even if they were alone for the time being, but he was in favor of a Caledonian socialism that distributed the country's wealth more equitably while respecting each culture's identity (Les Calédoniens 23, IO-I6 July I975 [AJ-PC]).

The year ended with the killing of a young Kanak in Noumea by a French gendarme, who was exonerated by the court for shooting in selfdefense. Anticolonial protests and more police arrests followed, including that of Naisseline, again for a tract calling for a mass demonstration. The young activists of the Foulards Rouges and Groupe 1878 formed their own political party in 1976, Palika (Parti de Libération Kanak) and ran for office. The new party won two seats in the Territorial Assembly, one of which was held by now-High Chief Naisseline. What did Palika stand for, now that a former student movement had entered the mainstream? Groupe I 878's bulletin explained that Palika remained committed to multiethnic liberation but it prioritized the indigenous identity, and in keeping with the global anticolonial discourse of the era, it demanded Kanak socialist independence. That meant full sovereignty, the return of confiscated lands to the Kanak, the nationalization of the mines, and citizenship for all nonKanak who accepted Kanak nationality (Les Nouvelles I 878, 1975, 8-9 [AJ-PC]). Loyalist settler alarmists warned against a racial dictatorship, but an inclusive Kanak nationality was actually very Oceanian, given the indigenous notion that identity is defined by a web of social exchange relations. A Kanak-centered nationality would reposition the country in the Pacific, however, by abolishing the old colonial racial hierarchy, a change that had already caused settlers to flee from Algeria after 1962. In I979, Palika joined a new coalition, the Front Indépendantiste (FI), with four other parties to contest the Territorial Assembly election, and together they won fourteen seats out of thirty-six. Naisseline and others traveled to the South Pacific Forum of self-governing states and to the United Nations to appeal for help for the Kanak cause. He was again arrested for writing a radical tract calling for a demonstration after yet another Kanak was killed by a policeman (Association pour la fondation d'un institut Kanak d'histoire moderne [1982], 95-97). 
In I980, however, the Grande Terre members of Palika adopted a party platform of revolutionary "scientific socialism" led by a vanguard-style political bureau. Naisseline told me that two factors explained the resulting schism: One was the increasing leftism of young Kanak returning from studies in France, who opposed Naisseline's support of Kanak cooperatives and businesses; the second was the regional distinction between Grande Terre-where a harsher colonial legacy had pushed the leftists to prioritize land recovery and revolutionizing Kanak society along socialist lines-and the Loyalty Islands, which were entirely native reserves so that custom was more intact and respecting Kanak identity took priority. Groupe I 878 also criticized Naisseline's faction as a chiefly "personality cult." But what Naisseline argued for was a cultural liberation that would not "kill the Kanak people." As he put it: "Scientific socialism doesn't speak of Kanak society, of the Kanak nation." In early i98 I, his approach was outvoted by three to one and his faction was expelled from Palika, the party he had helped to inspire and to create. In response, he formed a new party, the Libération Kanak Socialiste (LKs) and remained in the Union Calédonienne-led Front Indépendantiste, while Palika withdrew from it. When Socialist François Mitterrand was elected president of France that year, Naisseline and other Fi leaders went to Paris to persuade him to support Kanak independence, but they later felt let down when that dream died (Naisseline 200I; Front Indépendantiste I98 I; Kanak, 29 Nov I98 I [AJ-PC]).

\section{From Radical Anticolonialist to Chiefly Politician}

While still a Front Indépendantiste member of the Territorial Assembly (TA) in I982-83, Naisseline participated in a power-sharing arrangement between centrist loyalists and the Front Indépendantiste, under the leadership of Vice President Jean-Marie Tjibaou, the Grande Terre Kanak leader of the Union Calédonienne. Naisseline voted with Tjibaou's coalition for a territorial income tax, to provide needed funding for self-government, and he criticized the right-wing loyalists allied with Chirac for their polarizing politics: "an ethnic divide has been dug in New Caledonia, dialogue no longer exists" (TA, 3 Dec I982, 6). He successfully supported reforming the marriage law, which had required that if one partner lived under French civil law and the other under Kanak custom, the couple had to live under civil law thereafter, along with their children. Continuing his cultural emphasis, Naisseline wanted Kanak custom to be as valid as French 
law: "We want to re-establish difference in order to mutually respect each other" (TA, I6 Dec I982, 4I). In I983, he advocated adapting other French laws to the local society: "What worries me is that we copy ... what happens in France and it's not efficient at all” (TA, 2 Feb I983, 4).

He also questioned a proposal to build a cultural center in Noumea in preparation for the 1984 Pacific Festival of Arts, giving a lengthy critique in the Governing Council of the ways that indigenous culture had been misrepresented by French anthropologists and the French Ministry of Culture. His role as high chief made him suspicious of outsiders who tried to define indigenous custom. "For the umpteenth time, you speak of Canaque culture," he complained. "People from the outside or elsewhere should no longer take our place and speak in the name of Canaques." He pointed out that French colonial policy had created two kinds of Kanak chiefs, one chosen traditionally and another administratively appointed. "I want to know, which culture are you talking about?" he asked. "Aren't you in the process of making Canaque culture either a subculture of Western culture or through the mediation of certain churches, making Canaque beliefs into sub-beliefs of Greco-Latin beliefs?" "You're trying to create a false Melanesian culture in place of the real one," he argued. "That doesn't come from us, it's an invention." In an ironic reference to Joseph Goebbels's infamous dictim, he added angrily, "When you speak of culture, for some time now, I've wanted to take out my revolver!" (TA, 3 Feb I983, 9-16). Yet when the Front Indépendantiste transformed into the Kanak Socialist National Liberation Front (FLNKS) in I984, formed a provisional revolutionary government with Tjibaou as president, and boycotted the Territorial Assembly elections, Naisseline, despite all his arrests in the I970s, refused to join them on the roadblocks. He was now estranged from both Palika and the UC-FLNKs.

Opposing intercommunal conflict, the Libération Kanak Socialiste chose instead to continue to engage with territorial institutions, participated in the 1984 elections, and won six seats, the most it would ever control. Naisseline pursued a moderate path of dialogue and backed a French compromise proposal for independence-in-association as a transition to multicultural independence. But it was too late, and violence escalated in the Kanak uprising. When Paris negotiated with Tjibaou instead of Naisseline, the Libération Kanak Socialiste, now a "marginal center," withdrew from the Territorial Assembly (Satineau 1987, 26-30). Naisseline's erudite syncretism of cultural nationalism and multiethnic socialist liberation was, in a sense, displaced by the more church-based Union 
Calédonienne of Tjibaou as well as by fellow Kanak radicals on Grande Terre, where native reserves were refugee camps from massive land alienation. Both groups also resented being led by a high chief from the Loyalty Islands, whose primary loyalty was now to his own lineage. Naisseline has remained in the margins of New Caledonian politics ever since, allying locally with various factions in the Islands Province while retaining his solitary LKS seat in the Territorial Assembly (now Congress). The important negotiated peace accords between Paris, the FLNKS, and loyalists, at Matignon-Oudinot in 1988 and Noumea in I998, brought him obvious relief: "We live almost in peace. It was unexpected: we were close to civil war" (l'Express, 5 Nov I998). Tjibaou was assassinated in 1989 by a Loyalty Islands Kanak from Ouvea whose community had stood up to France in 1988 and had suffered for it, whereas Tjibaou was at that time ready to compromise with Paris and the loyalists. Naisseline observed that Tjibaou had brought independence supporters together, but that now "people fight among themselves over his coffin" (NH, 22-28 June 2000).

Naisseline has become more reclusive over time and acquired a rather enigmatic, even contradictory image among some of his old comrades from the I960s and I970s. Gorodé called him "mysterious" (2000). Politically, he is a maverick distrusted by the Union Calédonienne and Palika, who are archrivals themselves. Former Groupe I 878 leaders have made the distinction that Naisseline's Foulards Rouges were mainly a Loyalty Islands movement that affirmed Kanak cultural identity, while Grande Terre Kanak had endured an exploitative colonialism and therefore supported the I980s uprising (Gorodé I975; Néaoutyine 2006). In 2000, Naisseline led a coalition against the FLNKS in the Islands Province elections, arguing that the FLNKS bureaucracy did not respect chiefs and clans, who needed "a true process of emancipation and sovereignty of the Islands" (NC, 3 July 2000). A friend of his from Polynesian Wallis and Futuna described Naisseline as playing the traditional "elder brother" role of upholding his own lineage and opposing outside meddling in Guahma (Moleana 2002). He retains some of his old Foulards Rouges friendships, including a few like Chivot who vote Libération Kanak Socialiste in Noumea, and he has supported allowing Kanak women into the new Customary Senate, since it is not traditional (Kanaky Online, 24 Aug 2005). Naisseline is concerned about protecting the environment, but he criticizes outside environmentalists who try to speak for the Kanak, preferring to work through the new National Council of the Rights of the Indigenous People of New Caledonia (NC, II Oct 2002). ${ }^{27}$ In 2002, the middle-aged high chief even 
managed to get himself arrested again, this time for punching the manager of a tourist diving club when he disrespected customary marine rights ( $N C$, I 5 Nov 2002).

At an LKS congress in 2003, Naisseline said of the former Foulards Rouges, "Some are still in politics, others are scattered, a little disappointed in politics, engaged instead in related movements, active in the milieu of civil society rather than parties." But anticolonialism was still alive, the Libération Kanak Socialiste vowed in its support for indigenous rights: "In moments of contestation, keeping each political movement's own originality can make sense ... but in an era of construction, like today, it's necessary to gather again to carry on the indigenous voice regarding unifying issues such as restricting the right to vote [on independence, to longterm residents], sharing sovereignty, territorial identity symbols, control over immigration, favoring locals in hiring or job training" (NC, 24-28 Jan 2003). Naisseline worried about the powerful foreign corporations that were helping Grande Terre to develop new nickel mines and processing plants: "Today, Caledonia is no longer a problem of French decolonization. We must see France differently, not as a colonial state, which it no longer is, but as an ally who can help us to struggle against the power of multinationals who, here as elsewhere in the world, can scramble the cards" (NC, I March 2003). Yet he pushed for a Kanak director of Aircal, the domestic carrier that enabled so many Loyalty Islanders to commute to work in Noumea, and for Islands Province ownership of the airline (NC, Io March 2007). ${ }^{28}$ Most residents of Guahma still vote for him, and in the 2008 municipal election on Maré, he backed one of his subjects, who led the Indigenous Rally list to victory, in coalition with a former Guahma dissident (NC, I 5 March 2008).

Nidoish Naisseline is a brilliant, complex leader. As with others in his generation, his intellectual discourse has combined inspiration from mainly francophone anticolonial authors, such as Césaire, Fanon, Memmi, Sartre, and Jaulin, with personal adaptations based on his own experiences as a Kanak in New Caledonia. The colonial regime once labeled him the creator of "an aggressive négritude" inspired by Stokely Carmichael's Black Power movement, and it accused him of proposing (no doubt sarcastically) that the European settlers should be confined to reserves and made to dance the waltz to entertain African-American tourists (Fonds I07W: I606:I04, I09 [ATNC]). He admitted to me that he was at times a bit racist in his youth, but he has also advocated dialogue with other communities (Naisseline 200I). His discourse was not simply derivative 
but rather syncretic like many Third World writings of the time. In many ways, including the use of local history and cultural metaphors, it talked back to Western philosophers such as Hegel and Aristotle, thereby asserting the mana of an indigenous critique of colonial assimilation. It is often challenging to reconcile custom and "development," as Naisseline's father had found in his own postwar political fluctuations, as Tjibaou realized before his tragic death (Bensa and Wittersheim I998), and as chiefly leaders in Tonga and Sāmoa discovered even after independence (Chappell I999). Some outside analysts have tried to blame instability in Melanesian states on the indigenous cultures, but the disruptive changes wrought by colonialism and economic "modernization" must also be examined. As the anticolonial writers that Naisseline once studied pointed out, the Third World still exists because of structural disadvantages that globalization has imposed on it (Chappell 2005).

In a sense, Nidoish Naisseline has been on a long voyage of exploration, from his father's chiefdom on Maré, a Kanak reserve, through colonial Noumea, to revolutionary Paris and back, navigating like other young Kanak and Caledonians between assimilation and association, cultural nationalism and global leftism, Oceania and the West. He has argued that "custom" is above all an exchange, and that thus "there is no contradiction between being rooted and going out into the world, or between tradition and modernity" (Kanaky Online, 9 Aug 2005). He has been called both a hero and a traitor, depending on who was trying to categorize him and when, and yet he has always been Nidoish Naisseline, like the other namesakes in his genealogy who ruled Guahma. Despite his purported zigzags, he has, in my opinion, remained rather consistent in his desire to see that Kanak cultural identity is respected and protected while still dialoguing with other ethnic groups and with France to seek greater self-determination within the borders that colonialism has created around his home island. If his voice is not as loud now as it once was in New Caledonia, it has still been important in Guahma, the Islands Province, and at times in Noumea. In June 2007, he surprised people by installing his son Dokucas as high chief, just as he had inherited the title while his own father was still alive over thirty years earlier ( $N C$, 7 June 2007). But then he maneuvered in the Congress with an LKS delegate from Noumea to enable the FLNKS to have four ministerial portfolios out of eleven, instead of only three. ${ }^{29} \mathrm{He}$ predicted that there would be more such actions in the future, to enable a new group of centrist loyalists to work with the FLNKS, as in 1982, and thus keep the right-wing Gaullists from polarizing the country again (NC, 
I 8 Aug 2007). Nidoish Naisseline tends his own garden now, like a wily Candide, but when needed, he can still pack a punch.

\section{Notes}

I The official Archives Territoriales de la Nouvelle-Calédonie (ATNC) contains the invaluable Fonds ro7W, with contemporary government and radical documents, as well as files such as the Correspondence of Raymond Leenhardt, and now-defunct newspapers like Voix du Cagou and France Australe.

2 Derived from the Hawaiian word kanaka (person), which traveled around the Pacific in shipboard and plantation pidgin in the nineteenth century and became Canaque in French, this spelling (Kanak) began to be used as a collective indigenous identity by the Foulards Rouges in I973. It is now invariable, as Oceanian languages do not show plural or feminine in the same ways that French does. Once pejorative, the label Kanak became now a symbol of pride.

3 Raymond Betts showed that while Paris talked assimilation, local colonial administrators such as Leon Faidherbe, Joseph Gallieni, and Hubert Lyautey developed a policy "on the ground" of leaving indigenous peoples as much as possible under their own customs and leaders in a form of protectorate (I96I). In theory, economic development, controlled by Europeans, would gradually win over the native peoples, though this cost-cutting form of colonial rule more often left them marginalized and impoverished. The old distinction between British "indirect rule" and French assimilation was thus more rhetorical than accurate, and included bending indigenous customs and leadership to suit colonial administrative and settler interests (see Chappell 2005). In New Caledonia, Isabelle Merle's data confirm these expedient practices (I995).

4 The term decolonization can mean different things, as United Nations General Assembly Resolution I 54 I showed in I960 when it proposed a choice among sovereign independence (what people often envision); free association (self-governing but still tied to the colonizer in some ways, usually economic or military); or integration into the colonizer (eg, as a state in the United States, with full citizenship rights that supposedly end unequal status). Between I962 and I980, nine colonies administered by Britain, Australia, or New Zealand became independent: Western Sāmoa, Nauru, Fiji, Tonga, Papua New Guinea, Solomon Islands, Tuvalu, Kiribati, and Vanuatu (ruled jointly with France), while the Cook Islands and Niue became self-governing in free association with New Zealand, without the strategic claims the United States has in Micronesia.

5 I discuss that broader subject in a book project entitled "The Black and the Red: Awakening the Nation in I970s New Caledonia" (manuscript in preparation). 
6 The publication has recently been released in English translation (Fraser and Trotter 2005).

7 Tjibaou became president of the Provisional Government of Kanaky in I 984 and was martyred by an assassin in I989. His importance to the Kanak nationalist movement is demonstrated by its naming of the Kanak cultural center outside Noumea after him, and his life has been described by Alain Rollat (1989) and Hamid Mokaddem (2005) in French, and in a superb new study in English by Eric Waddell (2008).

8 In I774, British explorer James Cook thought the main island, Grande Terre, resembled Scotland, the "old" Caledonia. France took possession in I 853 , adding the outer Loyalty Islands in I 864 .

9 Lapita actually comes from a mispronounced Kanak word meaning to dig a hole.

Io The ethnicity of the Lapita-makers at Teouma seems "mixed" from our present-day viewpoint; the skeletons show a high tendency toward gout, which is traceable to the Aborigines of Taiwan, yet they lack a key genetic mutation that would give them physical features more like today's Polynesians. See Buckley and others 2007, and Matisoo-Smith and others 2007, for preliminary DNA findings. The "Melanesian" component in Lapita-making, which seems to have originated in the Bismarck Archipelago, has often been neglected in the literature.

I I The few skulls found in the graves do not fit the many bodies buried at the site.

I 2 Archives Jean-Paul Caillard (AJ-PC), in Noumea, is a private collection of documents and often defunct publications such as Cité Nouvelle, Christianisme Social, Réveil Canaque (RC), Trait d'Union, AWA, papers of the Union Jeunesse Calédonienne (UJC), Les Calédoniens, Canaque Homme Libre, papers of the Groupe d'Action pour l'Indépendance Accéléré de la Calédonie, Kanak (Palika bulletin), and Les Nouvelles I 878 (or Andi Ma Dhô), published by Groupe 1978 .

I 3 Protestantism was historically a persecuted minority sect in France, and it also spawned a movement of social conscience to help the poor, including indigenous colonial subjects, against oppression.

I 4 The point of this analogy is simply to highlight the dramatic political reversal in New Caledonia's status, despite multiple objections by the overwhelmingly autonomist assembly in Noumea. But the demography of Hawai'i and New Caledonia are also in some ways similar, in that residents of European descent are not a majority in either place, and neither are the indigenous people. It is a situation that gives Asian and other Pacific Islander immigrants a crucial "swing vote" in elections and referendums, particularly in Hawai'i.

I 5 This refers to Sartre's “Orphée Noir" preface to Senghor I 948.

I 6 This vision predates but corresponds closely to Tjibaou's view that Kanak identity was ahead of them. See Bensa and Wittersheim I998, 380, and Fraser and Trotter 2005 , I60. 
I7 For more on the I93 I Colonial Exposition, see the essays on the topic in Mwà Véé I3, July I996.

I 8 Cabral was leader of the armed liberation struggle in Portuguese Guinea in West Africa, and his ideas were translated into French in the I960s. Naisseline told me that he had read them with great interest, along with writings from revolutionary Latin America in French translation.

I9 Fonds I07W, 799, Risterucci Report 3 I0, I3 Aug I969 (ATNC).

20 In early I970, Jaulin had organized a colloquium on "Ethnocide in the Americas." In that year he also published a collection of texts entitled De l'Ethnocide (Jaulin I970).

2I As a Communist, Césaire campaigned successfully after World War II for his home island of Martinique to become a French department, in order to abolish racial discrimination. But he later regretted the resultant lack of self-governing powers, and as longtime mayor of Fort-de-France he formed his own progressive party.

22 Uregei's Union Multiraciale de la Nouvelle-Calédonie initially enlisted the Foulards Rouges in its ranks.

23 Borrowed from settler-ruled Algeria in the I880s, the indigénat system assigned Kanak to native reserves, where they were policed by gendarmes and appointed chiefs. They had no French citizenship rights until I946.

24 Naisseline was referring here to African-American civil rights leader Martin Luther King Jr; Mahatma Mohandas Gandhi, a major spiritual and political leader of the Indian independence movement; and Eldridge Cleaver, a prominent civil rights activist and member of the Black Panther Party.

25 In 1959, Governor Laurent Pechoux had begun to take back autonomy powers granted in I956-58; then in 1963 the Jacquinot Law revoked the ministerial powers of the members of the Governing Council. In I969, the Billotte Laws removed local control over mining, large investments, and municipal elections.

26 France is composed of departments, somewhat like states in the United States but much more tightly controlled by the central government and led by appointed prefects.

27 Some French authors claim a discontinuity in this movement (which was formalized in the I990s with UN support for indigenous rights) because of the environmentalist trend it has followed after I998. Analysts have even questioned the legitimacy of some of its current leaders who are ex-members of the UC-FLNKS or Palika. But the "first occupant" argument was used by Naisseline and others as early as 1975, and in I98 I Eloi Machoro spoke to the World Council of Indigenous Peoples in Australia about the Kanak struggle.

28 Naisseline had formerly been director of Aircal before he was demoted to president of its administrative council. He had also served as president of the Islands Province before a dissident subject replaced him.

29 In 2004 , of 54 congressional seats, pro-independence parties, per se, had 
won I 8 and loyalists 36, but Christiane Gambey of the Libération Kanak Socialiste acquired a seat by running on the centrist Avenir Ensemble (Future Together) list from Noumea. Gambey said she opposed the polarizing polemics of Pierre Frogier of the Gaullist Rassemblement pour la Calédonie dans la République (Rally for Caledonia in the Republic), so she submitted a blank ballot in the vote for renewing the territorial executive, thereby reducing the total loyalist votes to 35. By the mathematics of proportional representation, this enabled the FLNKS to gain an additional cabinet post. It does not, however, change the fact that, due in part to the state-orchestrated immigration of the I970s, independence has the support of only one-third of the electorate (but about 80 percent of Kanak, who comprise 45 percent of the population).

\section{References}

AJ-PC, Archives Jean-Paul Caillard. Private collection of documents and publications. Noumea.

Aldrich, Robert

I993 France and the South Pacific since I940. Honolulu: University of Hawai'i Press.

Aristotle

I98 I The Politics/Aristotle. Translated by T A Sinclair. Revised and re-presented by Trevor Saunders. London: Penguin Books.

Association pour la fondation d'un institut Kanak d'histoire moderne

[I982] Contribution à l'histoire du pays Kanak. Noumea: Edition IKs.

ATNC, Archives Territoriales de la Nouvelle-Calédonie. Official government collection of government and radical documents, historical correspondence, and newspapers. Noumea.

Bensa, Alban, and Eric Wittersheim

I996 La Présence Kanak. Paris: Odile Jacob.

I998 Nationalism and Independence: The Political Thought of Jean-Marie Tjibaou. The Contemporary Pacific ı0:369-390.

Betts, Raymond

I96I Assimilation and Association in French Colonial Theory, I890-I9I4.

New York: Columbia University Press.

Bobin, Frédéric

I99I Caldoches, Metropolitans and the Mother Country. Journal of Pacific History 26 (2): 303-3 I 2.

Bouvier, Jean

I967 Les Rothschild. Paris: Fayard.

Brou, Bernard

I977 Prehistoire et Société Traditionelle de la Nouvelle-Calédonie. Publica- 
tions de la Société d'études historiques de la Nouvelle-Calédonie (SEHNC) I6. Noumea: SEHNC.

Buckley, Hallie, N G Tayles, and Rachel Fuller

2007 The People of Teouma: Update on Research Findings concerning Health and Disease. Paper presented at "Islands in the Middle" conference on Vanuatu archaeology, Port Vila, July.

Chappell, David

I999 Transnationalism in Central Oceanian Politics: A Dialectic of Diasporas and Nationhood? Journal of the Polynesian Society I08 (3): 277-303.

2005 "Africanization" in the Pacific: Blaming Others for Disorder in the Periphery? Comparative Studies in Society and History 47 (2): 286317.

Charlot, Jean

I97I The Gaullist Phenomenon. London: Allen \& Unwin.

Clifford, James

1992 Person and Myth: Maurice Leenhardt in the Melanesian World. Durham, NC: Duke University Press.

Dauphiné, Joël

2007 Les Kanak dans le regard des savants. In Histoire de la Nouvelle-Calédonie: Approches Croisées, edited by Frédéric Angleviel, 7I-78. Paris: Indes Savantes.

Debord, Guy

I983 Society of the Spectacle. Detroit: Black and Red. Originally published as La Société du spectacle, in 1967.

Dornoy, Myriam

I984 Politics in New Caledonia. Sydney: University of Sydney Press.

Dubois, Marie-Joseph

I98 I Histoire Résume de Maré (Iles Loyauté). Noumea: SEHNC.

L'Express. Paris weekly news magazine.

Fanon, Frantz

I967 Black Skin, White Masks. Translated by Charles Lam Markmann. New York: Grove Press. Originally published as Peau noire, masques blancs, in 1952 .

I968 The Wretched of the Earth. Preface by Jean-Paul Sartre; translated by Constance Farrington. New York: Grove Press. Originally published as Les damnés de la terre, in $\mathrm{I} 96 \mathrm{I}$

I969 Toward the African Revolution. Translated from the French by Haakon Chevalier. New York: Grove Press. Originally published as Pour la révolution africaine, in 1964.

Firth, Stewart

I987 Nuclear Playground. South Seas Books. Honolulu: University of Hawai'i Pacific Islands Studies Program and University of Hawai'i Press. 
Fraser, Helen, and John Trotter, editors and translators 2005 Jean-Marie Tjibaou: Kanaky. Canberra: Pandanus Books.

Front Indépendantiste I98 I Première Convention Territoriale, I4-I 5 March. Noumea, pamphlet.

Gorodé, Déwé

I975 Nouvelle-Calédonie: Colonisation et Decolonisation. Speech given at "Conference for a Nuclear Free Pacific," Suva, Fiji, April.

2000 Interview with author, in Noumea, 22 June.

200I The Faces of Déwé Gorodé. Pacific Magazine (Suva), May.

Guiart, Jean

I963 Structure de la Chefferie en Mélanésie du Sud. Paris: Musée de l'Homme, Institut d'Ethnologie.

Hargreaves, John

I967 West Africa: The Former French States. Englewood Cliffs, NJ: PrenticeHall.

Hegel, Georg W F

I953 The Philosophy of Hegel, edited by Carl Friedrich. New York: Modern Library.

Henningham, Stephen

I992 France and the South Pacific: A Contemporary History. South Seas Books. Honolulu: University of Hawai'i Center for Pacific Islands Studies and University of Hawai'i Press.

Howe, Kerry

I978 The Fortunes of the Naisilines: Portrait of a Chieftainship. In More Pacific Islands Portraits, edited by Deryck Scarr, I-I7. Canberra: The Australian National University.

Jaulin, Robert, editor I970 De l'Ethnocide. Paris: Io/I8.

Kanaky Online. http://fr.groups.yahoo.com/group/kanaky/message

Kirch, Patrick

2000 On the Road of the Winds: An Archaeological History of the Pacific Islands before European Contact. Berkeley: University of California Press.

Le Borgne, Jean 2006 Nouvelle-Calédonie 1945-68: La Confiance Trahie. Paris: Harmattan.

Leenhardt, Maurice

I979 Do Kamo: Person and Myth in the Melanesian World. Chicago: University of Chicago Press. Originally published as Do kamo; la personne et le mythe dans le monde mélanésien, in I947.

Matisoo-Smith, Lisa, Melanie Pierson, and Judith Robins

2007 An Update on the DNA of Teouma Remains. Paper presented at the 
"Islands in the Middle" conference on Vanuatu archaeology, Port Vila, July.

Memmi, Albert

I967 The Colonizer and the Colonized. Boston: Beacon Press. Originally published as Portrait du colonisé, précédé par Portrait du colonisateu, in 1957 .

Merle, Isabelle

I995 Expériences Coloniales: La Nouvelle-Calédonie (I853-I920). Paris: Belin.

Mokaddem, Hamid

2005 Ce souffle venu des ancêtres: L'oeuvre politique de Jean-Marie Tjibaou (1936-1989). Noumea: Expressions.

Moleana, Atelemo

2002 Interview with author, in Noumea, 2 I October.

Mwà Véé: Revue Culturelle Kanak [journal; various periods] Noumea: Agence de développement de la culture Kanak.

Naisseline, Nidoish

200I Interview with author, Noumea, 2I February.

Néaoutyine, Paul

2006 L'Indépendance au Présent: Identité Kanak et Destin Commun. Paris: Syllepse.

NC, Les Nouvelles-Calédoniennes. Noumea daily.

NH, Les Nouvelles-Hebdomadaire. Noumea weekly.

Ounei, Susanna

I984 New Caledonia: Women and the Kanak Liberation Struggle. Talk delivered at Auckland University, November. Available online via http://www .ibiblio.org

Pagden, Anthony

I982 The Fall of Natural Man: The American Indian and the Origins of Comparative Ethnology. New York: Cambridge University Press.

Plato

2005 The Laws. Edited and translated by Trevor J Saunders. Preface by Richard Stalley. New York: Penguin Books.

2007 The Republic. Translated by Desmond Lee. Introduction by Melissa Lane. New York: Penguin Books.

Rollat, Alain

I989 Tjibaou le Kanak. Lyon: La Manufacture.

Sand, Christophe

2005 "Le Temps d'Avant": la Prehistoire de la Nouvelle-Calédonie. Paris: Harmattan. 
Sartre, Jean-Paul

I992 Being and Nothingness. Translated and with an introduction by Hazel E Barnes. New York: Simon \& Schuster. Originally published as L'être et le néant, in 1943 .

Satineau, Maurice

I987 Le Miroir de Nouméa: La Classe Politique Française Face à la Crise Calédonienne. Paris: Harmattan.

Senghor, Léopold, editor

I948 Anthologie de la Nouvelle Poésie Nègre et Malagache de Langue Française. Paris: Presses Universitaires de France.

TA, Assemblée Territoriale de la Nouvelle-Calédonie

I982-I983 Records of the Territorial Assembly, Sixth Legislature.Noumea.

Trolue, Fote

200I Interview with author, in Noumea, 20 February.

Waddell, Eric

2008 Jean-Marie Tjibaou, Kanak Witness to the World: An Intellectual Biography. Pacific Islands Monograph Series 23. Honolulu: University of Hawai'i Center for Pacific Islands Studies and University of Hawai'i Press.

\section{Abstract}

Studies of the Kanak independence movement have tended to focus on the turbulent I980s in New Caledonia and their aftermath, but the roots of the modern nationalist movement go back to Kanak and Caledonian students who attended universities in France in the I960s. They were radicalized by what they experienced, including the May I968 student-worker uprising, and they went home again in 1969 to find colonialism alive and well in their own country. Their protest movement gradually grew into a pro-independence political party, when JeanMarie Tjibaou was still a moderate cultural activist and political autonomist. The words and actions of Nidoish Naisseline, in particular, merit closer examination in tracing the genealogy of anticolonial Kanak and Caledonian radicalism. They show that when he became high chief on an outer island, his own politics began to change, though he remains to this day a local leader who supports indigenous rights.

KEYwOrDs: New Caledonia, Nidoish Naisseline, Foulards Rouges, Kanak independence, anticolonialism, Third World 